Article

\title{
Education for Sustainable Development in STEM (Technical Drawing): Learning Approach and Method for SDG 11 in Classrooms
}

\author{
Francisco Del Cerro Velázquez ${ }^{\mathbb{D}}$ and Fernando Lozano Rivas * \\ Department of Electromagnetism and Electronics. Faculty of Chemistry, Campus of Espinardo, 5, \\ 30100 Espinardo, Murcia, Spain; fcerro@um.es \\ * Correspondence: fernando.lozano@um.es
}

Received: 21 January 2020; Accepted: 17 March 2020; Published: 30 March 2020

check for updates

\begin{abstract}
Five years after proclamation of the Sustainable Development Goals promoted by the United Nations, Spain joined this process of transforming the world socially, economically, and environmentally. This research covers the route taken and results obtained during subsequent years in Spain and proposes, as a general objective, to observe whether it is feasible to work in the technical drawing classroom on an eco-urban project, following the learning approach and method proposed by the United Nations Educational, Scientific, and Cultural Organization (UNESCO) in 2017 Education for Sustainable Development Goals: Learning objectives, in order to reinforce cognitive, socio-emotional, and behavioral objectives, as well as the key competences established in Sustainable Development Goal 11. The phases of the project were related to the learning objectives and key competences, the results of which were complemented by a questionnaire that provided information on the sustainable consciousness of the students after completing the project, and could serve as a starting point for future educational projects. We agree with other authors, and in particular with UNESCO, that implementation of this type of project in the classroom is a key learning method for SDG.
\end{abstract}

Keywords: sustainable awareness; SDGs; sustainable cities and communities; eco-urban technical project

\section{Introduction}

\subsection{History of Sustainable Development Goals in Spain 2015-2019}

In September 2015, the United Nations established the roadmap towards improving the planet from different social, economic, and environmental perspectives, and the Sustainable Development Goals (SDGs) were born. Four years after the 2030 Agenda, we ask whether future generations are aware of the Goals; whether it is possible to inculcate a sustainable conscience in society, and what have been the results to date.

On the 18th of June 2018, the Government of Spain created the High Commissioner for 2030 Agenda, whose duties are set out in Article 11 of Royal Decree 419/2018 [1]. These are to:

(a) Monitor the actions of the competent bodies of the General State Administration concerning compliance with the goals of sustainable development and the 2030 Agenda.

(b) Promote the preparation and development of the plans and strategies necessary for Spain to comply with the 2030 Agenda.

(c) Evaluate, verify, and disseminate the degree of progress towards the compliance with the goals of the 2030 Agenda. 
(d) Collaborate with the Ministry of Foreign Affairs and Cooperation in Spain's international dialogue concerning global implementation of the 2030 Agenda.

(e) Promote the information and statistical systems necessary to accredit the progress made in achieving the goals of the 2030 Agenda.

In the same way, the Spanish Government created a website specifically dedicated to the 2030 Agenda [2], which offers general information on the SDGs and the government's current actions, and ontains a presentation from the High Commissioner and a resources section. This website is similar to the official website of the United Nations.

One month later, on the 18th of July 2018, the action plan for the implementation of the 2030 Agenda (Towards a Spanish Strategy for Sustainable Development) was published. According to this document published by the Ministry of Foreign Affairs [3], the educational model of the country must respond to the commitments agreed on in September 2015 "by including in the educational curriculum mechanisms that provide students with tools to understand the world, with socio-affective skills to manage it and to give critical capacity, so that values of human dignity, equality, justice, solidarity and participation are fostered" (p. 29). The same section of the document establishes that it is essential to include competencies in the educational framework that are directly related to ethical values favorable to social, environmental, and economic sustainability in the curricular contents of formal education at all levels. Likewise, it states that "it is essential that the proposed educational model responds to the commitments acquired within the framework of the SDGs."

Spain has been part of the negotiations on the 2030 Agenda, and is committed at an international level to the establishment of the SDGs and in favor of international cooperation, such as in the Ibero-American Conference and its General Secretariat, the Economic Commission for Latin America, and the Organization of American States.

In its 2016 report, The Policy Coherence for Development Index, a tool created to measure, evaluate, and compare the commitment of countries to sustainable, fair, and equitable human development, the following results, which can be seen in Figure 1 [4], were described.
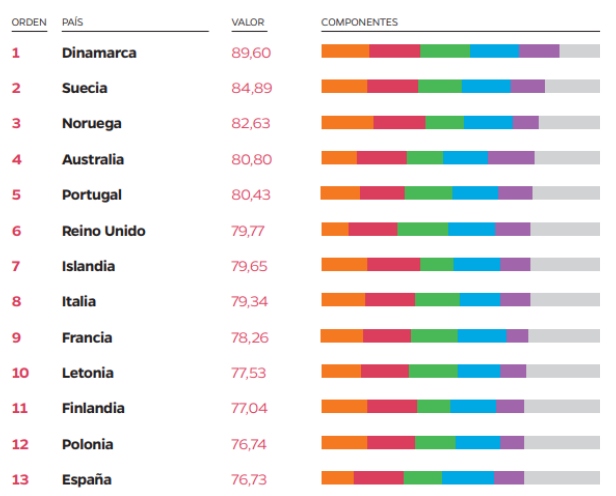

Figure 1. Policy Coherence for Sustainable Development Index (PCSDI) 2016 Ranking.

The most redistributive countries were those at the top of economic ranking, led by the Nordic countries. Respect for the social component produced good overall results, while those concerning the global component showed that the countries best-placed in the PCSDI (Policy Coherence for Sustainable Development Index) occupied the highest positions. An overview of the environmental component revealed very uniform results, in which countries tended to have relatively similar scores. However, these scores concealed enormous differences in development models, whereby certain countries that, although they were responsible for creating strongly negative environmental pressure, had the capacity to incorporate policies that "compensated" for their failings. The productive component identified only one European country, Denmark, among the first 20 places in the ranking.

What conclusions can be drawn from this study with respect to Spain? 
As can be seen in Figure 2, the results of the report show that the Spanish index is among the top 15 countries in the ranking of the 133 participants in the study. Comparing Spain with its performance in each of the components, it can be seen that this country fares badly in almost all them, and the global component is the only one in which its position is high.

\begin{tabular}{|c|c|c|c|c|c|}
\hline \multicolumn{7}{|c|}{ Desempeño de España por componentes } \\
\hline ICPD & Económico & Social & Global & Ambiental & Productivo \\
\hline 13 & 33 & 41 & 4 & 44 & 66 \\
\hline Baja/sube & -20 & -28 & +9 & -31 & -53 \\
\hline
\end{tabular}

Figure 2. Spain's score for each component. PCSDI 2016.

Compared with other EU countries, Spain's position is medium-high, as it ranks tenth. Two conclusions that are considered important for the present research can be drawn from the report:

- $\quad$ Spain has ample room for improvement in terms of policy coherence for development, especially in social, environmental, and productive areas.

- The countries of the European Union present great heterogeneity in terms of their observance of policies for development, although in some components, including the global performance.

In October 2018, the Spanish Network for Sustainable Development published a report entitled Looking to the Future: Sustainable Cities. In the presentation of the report, reference is made to the following: [5].

The SDGs offer a set of integrated goals for more prosperous, fairer and environmentally sustainable cities. In particular, SDG 11 calls for our cities to be inclusive, safe, resilient and sustainable. The SDG Agenda gives us an impartial and long-term framework for achieving these ambitious and noble goals.

The Report reviews the 17 SDGs and presents the challenges that eco-urbanism represents as a model city in terms of mobility, health, inequalities, and climate change.

According to the latest report by the Sustainable Development Solutions Network (SDSN), Spain ranks 21st in the "SDG 2019 Index". Figure 3 shows both the current assessment and the trend for each of the Sustainable Development Goals for Horizon 2030.

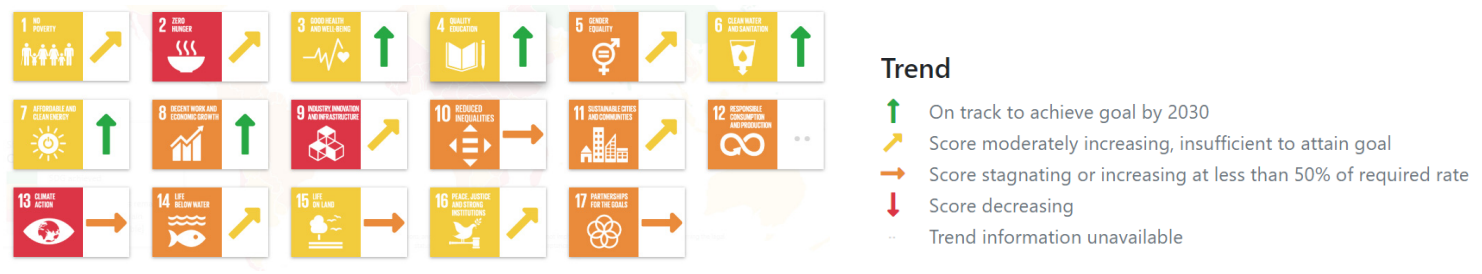

Figure 3. Sustainable Development Report 2019.

The report includes contributions from Professor Jeffrey D. Sachs (Columbia University), the Office of the Prime Minister of Finland and the World Business Council on Sustainable Development (WBCSD). For the first time, the results of the study were statistically audited by the European Commission.

From the data provided, it can be seen that, as of June 2019, Spain did not obtain the highest possible rating for any component and none of the SDGs are green, so that if the trend continues, Spain will not reach any SDG by the 2030 horizon. The greatest challenges are the SDGs relating to No Poverty, Climate Action, Industry, Innovation, and Infrastructure, and the country obtains its best results for SDG 6 (Clean Water and Sanitation) and SDG 7 (Affordable and Clean Energy). The top three countries of the 162 in the study are Denmark, Sweden, and Finland. 


\subsection{Denmark, Sweden, and Finland: the Model to Follow}

According to the latest report of the Sustainable Development Solutions Network [6], Denmark is the first country in the ranking to achieve the SDGs: Figure 4 shows how the trend in both SDG 4 Quality Education and SDG 11 Sustainable Cities and communities is on track to achieve the Goals in 2030 .

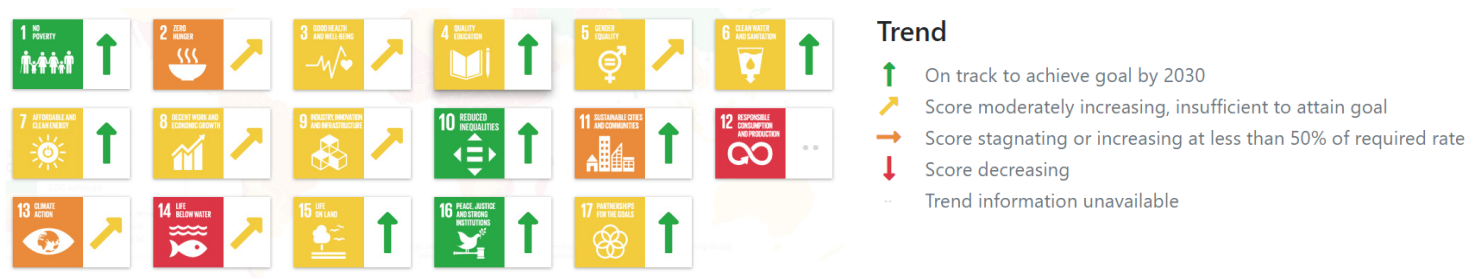

Figure 4. Sustainable Development Report 2019. Denmark.

Analysis of the Danish education system points to the principles on which the Danish Ministry of Education and Vocational Training system is based [7]: "Education for all, high standards of quality, lifelong learning, active participation and project work". According to the document "The World is Studying Spanish. Denmark", published on the website of the Ministry of Education and Vocational Training, compulsory primary and secondary education takes place from six to sixteen years of age. In its last reform, the Danish education system made a change in the total number of teaching hours as well as in the distribution of subjects. The subjects with the highest number of hours are Danish and STEM.

The latest report published on Sustainable Development Solutions [8] identifies Sweden as the second-ranked country for fulfilling SDGs, and Figure 5 shows how the trend in both SDG 4 Quality Education and SDG 11 Sustainable Cities and Communities is on track to attain the corresponding goal in 2030 .

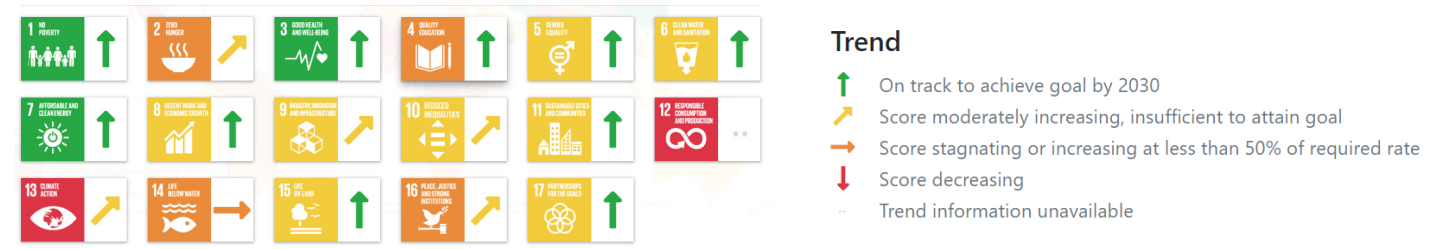

Figure 5. Sustainable Development Report 2019. Sweden.

Finland is the third country in the ranking for fulfilling SDGs: SDG 4 Quality Education has been achieved, and the SDG 11 Sustainable Cities and Communities is in a better position than its Danish counterpart (Figure 6).

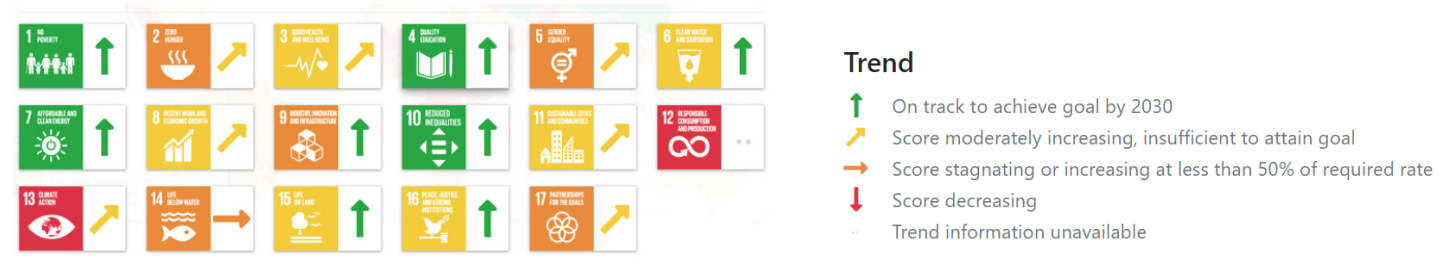

Figure 6. Sustainable Development Solutions Report 2019. Finland.

\subsection{The Educational City: Towards a Sustainable Awareness}

In any analysis of environmental education, it is necessary to refer to the Intergovernmental Conference on Environmental Education organized by UNESCO with the collaboration of PNUMA in 
Tbilisi in 1977. This conference discussed new ideas on environmental education and its dimension. The final report of the paper states [9] that,

Environmental education is an integral part of the education system, should be problem-oriented and interdisciplinary. It should tend to establish a sense of values, contribute to collective well-being and concern for human well-being.

Thus affirming that environmental education should form part of any educational system, and emphasizing the value placed on the collective well-being of humanity.

Subsequently, in 1980, UNESCO put into practice the main guidelines of the Tbilisi Conference, based on the 41 recommendations made in the conference, by establishing the purposes and pedagogical characteristics of environmental education.

However, the concept of sustainable development was not introduced until 1987, when the Brundtland Report, in Chapter 2 "Towards Sustainable Development", described it as development that meets the needs of the present generation without compromising the ability of future generations to meet their own needs [10].

In recent decades, the commitment to environmental education in different countries has become evident from public investment, information, and educational programs, etc., although measures for sustainable change have not been developed in the same way in all European societies. It is undoubtedly in the field of education that we must put greater energy and establish the necessary means so that, from the earliest ages, children grow up with a real idea of sustainable consciousness. Certain authors [11], advocate proposals for the "environmentalization" of educational centers and curricular sustainability, which would involve introducing sustainable and environmental content and criteria into the curriculum. Others insist on the importance of environmental education research at an early age [12].

With the progressive development that environmental education research has been experiencing from the university world, a more solid argument and a more grounded response about its usefulness is offered to society, less based on intuition and sporadic speculation; and more based on the valorization of empirical arguments to justify and document claims, prove achievements, compare evolution and justify changes at different levels.

From this perspective, it is true that many experts have participated in the Seminar on Education and Communication on Climate Change, which has been organized in Spain every year since 2004 with the aim of diagnosing the development in Spain of the Framework Convention on Climate Change, related to education, awareness, access to information, and participation on issues connected with climate change. Among other aspects, these training courses encourage to [11]:

Analyse the effectiveness of activities under the Climate Change Convention and examine the links between these activities, the implementation of policies and measures to mitigate change and Encourage the exchange of ideas and experiences and collaboration between people working on the promotion of renewable energy, energy saving, sustainable mobility and education.

At a local level, in Spain, we could say that the ESD has been visible in our educational system since 1990, with the Law of General Organization of the Educational System (LOGSE), since when educational projects and programs have been executed, such as School Agenda 21 in many Spanish regions, Green Schools in Catalonia, Educational Centers towards sustainability in La Rioja, or Sustainable Schools in Navarra. These programs have been consolidated through networking, such as the ESenRED network and schools towards sustainability online, which began in 2012 and involve almost 55,000 teachers and more than 1,100,000 students [13]. However, we still have a long way to go. We need to make the school curriculum sustainable so that, through sustainable projects, we can inculcate high levels of awareness among our students [14]. Sauvé, L. analyses that environmental education cannot be isolated from the contemporary social dynamic, characterized by various social movements of 
indignation and the progressive emergence of a citizenry that is increasingly aware of the inseparable links between social and ecological realities, and that calls for a renewed democracy to promote the common good. It is therefore necessary to prepare a critical eco-citizenship; emphasizing not only the economic and environmental, but also the social character in order to achieve a quality environmental education; parameters similar to those used for eco-urbanism as a methodological instrument are similarly mentioned by Del Cerro, F. and Lozano, F. [15].

To do so, from the educational point of view, it is essential to adapt the content, skills, and values that correspond to the teacher's performance, the social aspects, and consider the impact of their professional activity on the environment and its protection with sustainability criteria. This requires the epistemological bases that support a model based on the solution of the contradiction established to be defined between the cognitive, professional skills, and modes of action [16].

Del Cerro, F. and Lozano, F. [15] analyzed how sustainable development at its origin, later consolidated by the SDGs, encompass environmental, social, and economic aspects. At the same time, these characteristics converge with the pedagogical principles included in the Organic Law for the improvement of Quality Education. They affirm that:

Education is a fundamental way to achieve sustainable development. Classrooms are spaces where teachers can promote and instill values and attitudinal changes that allow achieving the goals of the SDGs. Therefore, it is easy to understand that SDG 4, Quality Education is fundamental to achieve, expand and effectively implement the rest of the SDGs.

The 2019 SDG Index and Dashboards Report for European Cities (prototype version) [17] looks at the scores obtained by 45 European cities. Figure 7 shows that the three cities with the highest overall score are Oslo, Stockholm, and Helsinki, with more than 70 points, while the Spanish cities of Madrid and Barcelona ranked 28th and 30th, respectively, with scores in the 55-60 range.

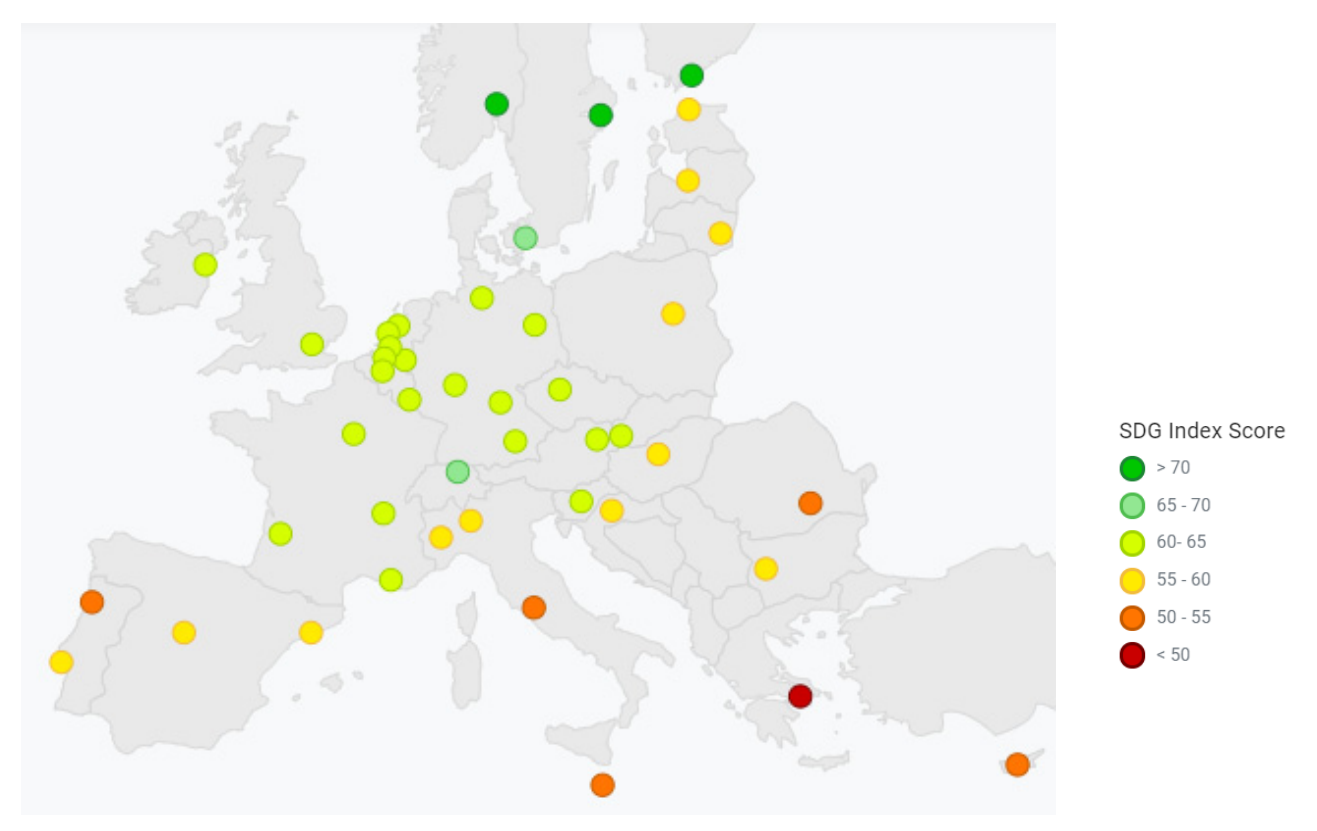

Figure 7. European Cities Sustainable Development Goals (SDGs) Index. Prototype Version (2019).

If we analyze the data from Oslo, the city occupying first place in the ranking, and compare the same with Madrid, we observe that, as shown in Table 1. 
Table 1. European Cities SDG Index. Prototype Version (2019). Quality Education.

\begin{tabular}{|c|c|c|c|}
\hline \multicolumn{2}{|r|}{ Oslo } & \multicolumn{2}{|c|}{ Madrid } \\
\hline \multicolumn{2}{|c|}{ Early leavers from education (18-24\%) } & \multicolumn{2}{|c|}{ Early leavers from education (18-24\%) } \\
\hline 8.50 & Yellow & 13.90 & Orange \\
\hline \multicolumn{2}{|c|}{ Adults with higher secondary education (25-64\%) } & \multicolumn{2}{|c|}{$\begin{array}{l}\text { Adults with higher secondary education } \\
\qquad(25-64 \%)\end{array}$} \\
\hline 84.20 & Yellow & 72.90 & Orange \\
\hline \multicolumn{2}{|c|}{ NEET rate $(15-24 \%)$} & \multicolumn{2}{|c|}{ NEET rate $(15-24 \%)$} \\
\hline 4.00 & Green & 10.40 & Yellow \\
\hline \multicolumn{2}{|c|}{ Satisfaction with schools (\%) } & \multicolumn{2}{|c|}{ Satisfaction with schools (\%) } \\
\hline 80.00 & Green & 50.00 & Red \\
\hline \multicolumn{2}{|c|}{ Four-year-olds in early childhood education (\%) } & \multicolumn{2}{|c|}{$\begin{array}{l}\text { Four-year-olds in early childhood education } \\
\qquad(\%)\end{array}$} \\
\hline 96.20 & Green & 98.10 & Green \\
\hline \multicolumn{2}{|c|}{ Adult participation in learning $(\%)$} & \multicolumn{2}{|c|}{ Adult participation in learning $(\%)$} \\
\hline 22.50 & Green & 11.50 & Orange \\
\hline \multicolumn{2}{|c|}{ University appearances in rankings } & \multicolumn{2}{|c|}{ University appearances in rankings } \\
\hline 4.00 & Yellow & 9.25 & Green \\
\hline \multicolumn{2}{|c|}{ Sustainable cities and communities } & & \\
\hline & SDG achieved & & \\
\hline & Challenges remain & & \\
\hline & Significant challenges remain & & \\
\hline & Major challenges remain & & \\
\hline d & Data missing & & \\
\hline
\end{tabular}

The most significant difference between all the indicators is the degree of satisfaction with the educational centers. In the case of Madrid, it is the only important challenge still to be faced (marked in red).

For UNESCO, education is fundamental, because it is a basic universal right and the foundation of peace and sustainable development. This United Nations agency maintains that education is fundamental to achieving the 17 SDGs included in the 2030 Agenda. Likewise, UNESCO has a follow-up plan, the Global Programme of Action on Education [18].

We live in a time where ESD is at its peak. It is sufficient to look around us and see how we live, what the model of our cities is, our habits, the conditions of the oceans, the quality of the air, the scarcity of water, etc. Only recently, in November 2018, did Madrid begin to restrict the access of certain vehicles to the city centre through Plan A for Air Quality and Climate Change; through this action, environmental and social objectives were pursued in relation with a reduction in $\mathrm{NO}_{2}$ emissions, a decrease in the level of noise, and the freeing up of public space. As Xabier Querol indicated: "In Europe there are 280 cities with traffic restriction zones, in Spain one". In his interview [19] in the digital newspaper El Diario.es, the researcher states that the measure is correct, but insufficient; he comments that in Germany ("inventors of the truth"), there are 50 cities with areas that limit the entry and circulation of the most polluting cars [20]. One of the most significant challenges worldwide is improving air quality; exposure to high levels of air pollutants can cause irreparable damage in humans and even death. The World Health Organization has established that $91 \%$ of the world's population lives in places where air quality "exceeds established limits", and that 4.2 million deaths each year occur as a result of exposure to air pollution [21].

There is no doubt the overpopulation and the erroneous model of our cities and settlements can only worsen the current situation, although certain countries are taking measures to curb the levels of emission of $\mathrm{NO}_{2}$ and $\mathrm{O}_{3}$, among others [22]. 
The most developed societies have been applying, for years, emission reduction policies that have generated, for the majority of pollutants, a decrease in pollution levels. On the other hand, the world population continues to grow markedly and the global tendency to concentrate the population in large and dense cities... All this has led to problems of urban air quality, not only because of an increase in the concentration of pollutants in many cases, but also because when moving to the city the population is more exposed to them.

It seems that certain sectors of society do worry about the condition of our planet, among them, international organizations, associations, NGOs, and the National Government itself, which are implementing actions and intervention plans to promote Sustainable Education. From the website of the Ministry for ecological transition, citizens are informed about energy poverty (manifestation of poverty and social exclusion), the heating allowances, the ITAIWP (Illegal Trade and International Wildlife Poaching) Plan, etc. Similarly, the Government, in its National Strategy against Energy Poverty 2019-2024, established measures to prevent situations in which households cannot cover their basic energy supply needs [23].

This research highlights other actions aimed at promoting ESD through education, more specifically through project's methodology. Indeed, this should be the responsibility of governments, the private sector, civil society, and every human being on the planet. The acquisition of SDGs is a universal task that must be carried out at local level, taking into account the environmental context and the socioeconomic aspects of each place. Irina Bokova, Director-General of UNESCO, states: [24].

A fundamental change is needed in the way we think about the role of education in global development, because it has a catalytic effect on the well-being of individuals and the future of our planet ... Now more than ever, education has a responsibility to keep pace with the challenges and aspirations of the 21st century, and to promote the right kinds of values and skills that will lead to sustainable and inclusive growth and a peaceful life.

From our position, we wonder, how we can enhance the training of our students to achieve a sustainable consciousness? STEM subjects can contribute to this, and, in the case that concerns us, Technical Drawing, must introduce practices relative to the projection of spaces of eco-urban coexistence, solving social, economic, and environmental problems. Today, there is an abyss between the reality of 21st century society, our technological and consumption-centered society, and the response of different educational systems, in which students are not educated on competent sustainability. Neither is this possible if teachers do not work from sustainable perspectives [25].

In 2017, UNESCO published the document Education for SDGs, Learning Objectives, which aimed boost ESD by offering a guide for teachers. Table 2 shows the list of specific learning objectives for SDGs and key competencies for sustainability.

This guide identifies specific learning objectives and suggests themes and activities for each SDG [26]. The document is designed to guide education professionals in the use of ESD in learning for SDGs and, consequently, for achieving them.

The technical project as a methodological tool has numerous benefits [27].

Several emerging pedagogies review the educator learner relationship and treat them, both, as partners in change or change agents. Moreover, they enable learners to experience authentic learning environment by working in inter and transdisciplinary teams to help communities overcome sustainability challenges with mutual benefits.

Similarly, key competencies for sustainability are described, as well as specific Learning Objectives for SDGs that allow people to be called "sustainability-conscious citizens" [28]. 
Table 2. List of specific learning objectives for the SDGs and key competencies for sustainability.

\begin{tabular}{|c|c|}
\hline Specific Learning Objectives for the SDGs & Key Competencies for Sustainability \\
\hline \multirow{3}{*}{$\begin{array}{l}\text { The cognitive domain comprises knowledge and } \\
\text { thinking skills necessary to better understand the } \\
\text { SDG and the challenges in achieving it. }\end{array}$} & $\begin{array}{l}\text { Systems thinking competency: The abilities to recognize and } \\
\text { understand relationships; to analyze complex systems; to think } \\
\text { of how systems are embedded within different domains and } \\
\text { different scales; and to deal with uncertainty. }\end{array}$ \\
\hline & $\begin{array}{l}\text { Anticipatory competency: The abilities to understand and } \\
\text { evaluate multiple futures-possible, probable, and desirable; to } \\
\text { create one's own visions for the future; to apply the } \\
\text { precautionary principle; to assess the consequences of actions; } \\
\text { and to deal with risks and changes. }\end{array}$ \\
\hline & $\begin{array}{l}\text { Normative competency: The abilities to understand and reflect } \\
\text { on the norms and values that underlie one's actions; and to } \\
\text { negotiate sustainability values, principles, goals, and targets, in a } \\
\text { context of conflicts of interests and trade-offs, uncertain } \\
\text { knowledge, and contradictions. }\end{array}$ \\
\hline \multirow{3}{*}{$\begin{array}{l}\text { The socio-emotional domain includes social skills } \\
\text { that enable learners to collaborate, negotiate, and } \\
\text { communicate to promote the SDGs as well as } \\
\text { self-reflection skills, values, attitudes, and } \\
\text { motivations that enable learners to } \\
\text { develop themselves. }\end{array}$} & $\begin{array}{l}\text { Strategic competency: The abilities to collectively develop and } \\
\text { implement innovative actions that further sustainability at the } \\
\text { local level and further afield. }\end{array}$ \\
\hline & $\begin{array}{l}\text { Collaboration competency: The abilities to learn from others; to } \\
\text { understand and respect the needs, perspectives, and actions of } \\
\text { others (empathy); to understand, relate to, and be sensitive to } \\
\text { others (empathic leadership); to deal with conflicts in a group; } \\
\text { and to facilitate collaborative and participatory problem solving. }\end{array}$ \\
\hline & $\begin{array}{l}\text { Critical thinking competency: The ability to question norms, } \\
\text { practices, and opinions; to reflect on own one's values, } \\
\text { perceptions, and actions; and to take a position in the } \\
\text { sustainability discourse. }\end{array}$ \\
\hline \multirow{2}{*}{$\begin{array}{l}\text { The behavioral domain describes } \\
\text { action competencies. }\end{array}$} & $\begin{array}{l}\text { Self-awareness competency: The ability to reflect on one's own } \\
\text { role in the local community and (global) society; to continually } \\
\text { evaluate and further motivate one's actions; and to deal with } \\
\text { one's feelings and desires. }\end{array}$ \\
\hline & $\begin{array}{l}\text { Integrated problem-solving competency: The overarching } \\
\text { ability to apply different problem-solving frameworks to } \\
\text { complex sustainability problems and develop viable, inclusive, } \\
\text { and equitable solution options that promote sustainable } \\
\text { development, integrating the above-mentioned competences. }\end{array}$ \\
\hline
\end{tabular}

Awareness that there is an environmental problem, a product of the way in which the planet has evolved and grown, is widespread. The spectator observes the deterioration around them, develops a cognitive and emotional dimension, knows what the problem is, and, for instance, feels the need to act. Nevertheless, the destruction of the environment is a fact. What is happening? A mere concern for the environment is not enough to stop its tarnishing; a sustainable consciousness is necessary in order to reactivate the tangential behavior that we have shown in the face of the problem. We acquire an environmental commitment when we reach an environmental consciousness, a multidimensional concept, in which several dimensions can be identified [22].

Cognitive: Degree of information and knowledge about environmental issues. This refers to ideas.

Affective: Perception of the environment; beliefs and feelings on environmental matters. This refers to emotions.

Conative: Willingness to adopt pro-environmental criteria in behavior, expressing interest or predisposition to participate in activities and make improvements. We talk about attitudes.

Active: Carrying out environmentally responsible practices and behavior, both individual and collective, even in compromised or pressure situations. We are talking about behaviors.

Therefore, integral Environmental awareness (EA) establishes a connection between several psychological constructs (knowledge, information, norms, values, attitudes, beliefs, etc.) that trigger behaviors that make it possible to coexist with the environment, preserve it, and transform it according to one's own needs, without compromising the possibility of future generations to satisfy theirs [29]. 
This concept is mentioned, almost in the same way, in the Brutland report in 1987, in which part 1 is $[10,30]$.

- Common concerns.

- Common tasks.

- Common efforts.

The current deteriorating environmental situation is of concern to a wide range of sectors, including psychologists. The cessation of the excessive exploitation of our natural environment requires a change in the way that people face it [31]. The New Environmental Paradigm (NEP) created by Dunlap and Van Liere in 1978 was born as an instrument to evaluate beliefs towards the environment. The scale consists of 12 items grouped in three dimensions, called: Limitations to the growth of society, the human capacity to alter the environmental balance, and the right of human being to govern or reign over nature. High scores in the NEP indicate an ecocentric orientation or commitment to the preservation of the environment, while low scores mean a predominance of anthropocentrism, that is, beliefs in favor of the exploitation of natural resources [32].

In 2000, Dunlap and collaborators included two new dimensions in the NEP scale, creating the New Ecological Paradigm (NEP), and increasing the number of items on the scale from 12 to 15 . Of these, eight offer a vision in favor of ecology and seven of them against ecology, objectifying people's environmental beliefs and therefore measuring them better than their previous version [33].

The question arises: Is it possible to link the phases of an Eco-urban Project in the technical drawing classroom, with the objectives and key competencies of SDG 11, and to put a value on Education for Sustainable Development?

The ultimate purpose of this research is to observe whether working on an eco-urban technical project in the classroom, using the methodological approach proposed by UNESCO (2017), strengthens the Learning Objectives (cognitive, socio-emotional and behavioral) and key competences established by UNESCO for SDG 11, sustainable cities and communities, and thus put a value on Education for Sustainable Development.

After the qualitative research has been carried out, a questionnaire is completed to observe, for information purposes only, the level of sustainable awareness that the students have reached at the end of the project.

\section{Materials and Methods}

\subsection{Method and Procedure: Project Phases, UNESCO Learning Objectives and Key Competencies}

As first part of the methodological design of the research, we detail the four phases of the eco-urban technical project carried out by the students:

- $\quad$ Background and current status analysis.

- Social study and feasibility of the area of action.

- Knowing your city: Planning space for coexistence.

- $\quad$ Design of the coexistence space. A 3D model.

Once the learning objectives and key competences have been described within the theoretical framework (see Tables 3-6), we relate each of the phases to the corresponding objectives and competencies by providing photographs, designs, and sketches related to the different work phases. 
Table 3. Phase 1 of the project: Background and analysis of current status.

\begin{tabular}{|c|c|c|}
\hline Phase of the Project & Learning Objective & Key Competence \\
\hline $\begin{array}{l}\text { During the study phase, students } \\
\text { carry out a critical analysis of the } \\
\text { school's living spaces. To this end, } \\
\text { they analyze the entire school } \\
\text { complex, its facilities, and spaces in } \\
\text { order to study the best area } \\
\text { for action. }\end{array}$ & $\begin{array}{l}\text { Cognitive learning objective } \\
\text { 1.2.11.1 The learner understands } \\
\text { basic physical, social, and } \\
\text { psychological human needs and is } \\
\text { able to identify how these needs are } \\
\text { currently addressed in their own } \\
\text { physical urban, peri-urban, and } \\
\text { rural settlements. }\end{array}$ & $\begin{array}{l}\text { Systems thinking competency: } \\
\text { The abilities to recognize and } \\
\text { understand relationships; to analyze } \\
\text { complex systems; to think of how } \\
\text { systems are embedded within } \\
\text { different domains and different } \\
\text { scales; and to deal with uncertainty. }\end{array}$ \\
\hline $\begin{array}{l}\text { The students study the historical } \\
\text { and urban background of the school } \\
\text { and analyze photographs taken as a } \\
\text { result of the research. They work } \\
\text { meticulously on the original } \\
\text { construction, the materials used, } \\
\text { and the possible construction } \\
\text { techniques used at the time. }\end{array}$ & $\begin{array}{l}\text { Cognitive learning objective } \\
\text { 1.2.11.3 The learner understands the } \\
\text { historical reasons for settlement } \\
\text { patterns and, while respecting } \\
\text { cultural heritage, understands the } \\
\text { need to find compromises to develop } \\
\text { an improved sustainable system. }\end{array}$ & $\begin{array}{l}\text { Anticipatory competency: The } \\
\text { abilities to understand and evaluate } \\
\text { multiple futures-possible, } \\
\text { probable, and desirable; to create } \\
\text { one's own visions for the future; to } \\
\text { apply the precautionary principle; to } \\
\text { assess the consequences of actions; } \\
\text { and to deal with risks and changes. }\end{array}$ \\
\hline 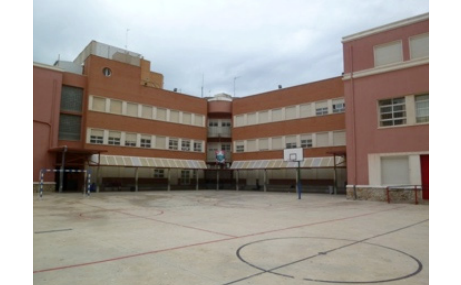 & Nusstro colecto & $=\int_{i}=1$ \\
\hline
\end{tabular}

Source: Own preparation: Photographs in the library and newspaper archives of the center, as well as current photos.

Table 4. Phase 2 of the project: Social study and feasibility of the area of action.

\begin{tabular}{|c|c|c|}
\hline Phase of the Project & Learning Objective & Key Competence \\
\hline $\begin{array}{l}\text { Students conduct interviews with } \\
\text { peers and the educational } \\
\text { community to learn about their } \\
\text { concerns and suggestions. By means } \\
\text { of flow diagrams elaborated with } \\
\text { models and colored threads, they } \\
\text { analyze the spaces of the center } \\
\text { more and less transited by their } \\
\text { companions and evaluate future } \\
\text { decisions of the project, taking into } \\
\text { account the needs of the educational } \\
\text { community, evaluating the possible } \\
\text { impacts of their decision. Through } \\
\text { brainstorming and sharing, they } \\
\text { reflect on the best choice of } \\
\text { sustainable opportunity space. They } \\
\text { highlight the social component that } \\
\text { is essential for ESD. } \\
\text { They take into account and value } \\
\text { aspects related to accessibility and } \\
\text { mobility of the future space of } \\
\text { coexistence. }\end{array}$ & $\begin{array}{l}\text { Socio-emotional learning } \\
\text { objectives 1.2.11.2 } \\
\text { The learner is able to connect with } \\
\text { and help community groups } \\
\text { locally and online in developing a } \\
\text { sustainable future vision of their } \\
\text { community. } \\
\text { Socio-emotional learning } \\
\text { objectives 1.2.11.4 } \\
\text { The learner is able to contextualize } \\
\text { their needs within the needs of the } \\
\text { greater surrounding ecosystems, } \\
\text { both locally and globally, for more } \\
\text { sustainable human settlements. } \\
\text { Socio-emotional learning } \\
\text { objectives 1.2.11.5 } \\
\text { The learner is able to feel } \\
\text { responsible for the environmental } \\
\text { and social impacts of their own } \\
\text { individual lifestyle. }\end{array}$ & $\begin{array}{l}\text { Anticipatory competency: The } \\
\text { abilities to understand and } \\
\text { evaluate multiple } \\
\text { futures-possible, probable, and } \\
\text { desirable; to create one's own } \\
\text { visions for the future; to apply the } \\
\text { precautionary principle; to assess } \\
\text { the consequences of actions; and } \\
\text { to deal with risks and changes. } \\
\text { Normative competency: The } \\
\text { abilities to understand and reflect } \\
\text { on the norms and values that } \\
\text { underlie one's actions; and to } \\
\text { negotiate sustainability values, } \\
\text { principles, goals, and targets, in a } \\
\text { context of conflicts of interests and } \\
\text { trade-offs, uncertain knowledge, } \\
\text { and contradictions. }\end{array}$ \\
\hline
\end{tabular}


Table 5. Phase 3 of the project: Knowing Your City. Approach to the Design of the space of coexistence.

\begin{tabular}{|c|c|c|}
\hline Phase of the Project & Learning Objective & Key Competence \\
\hline $\begin{array}{l}\text { Students discuss what to draw } \\
\text { inspiration from to project their } \\
\text { space of opportunity. Talking } \\
\text { among themselves, they come to } \\
\text { the conclusion that they are from } \\
\text { Cartagena, a maritime city, and } \\
\text { that their lives are linked to the } \\
\text { marine environment. Ideas, } \\
\text { sketches, and sketches of "future } \\
\text { ergonomic steps" inspired by the } \\
\text { waves of the sea are emerging. } \\
\text { They stroll through the city and } \\
\text { admire the marine architecture, } \\
\text { typical of the city of Cartagena. In } \\
\text { their visit to the city they analyze } \\
\text { how Cartagena has developed in } \\
\text { aspects related to green spaces, } \\
\text { accessibility, transport; evaluate } \\
\text { the decision making of the council, } \\
\text { in this case the Mayor of the city, } \\
\text { when investing money in the } \\
\text { public work. } \\
\text { The students thought of placing } \\
\text { pergolas at the beginning to offer } \\
\text { shaded areas, but finally they } \\
\text { understood that eco-urbanism is } \\
\text { important when designing, and } \\
\text { decided to place steel cables and } \\
\text { suspended from them } \\
\text { photovoltaic fabrics to take } \\
\text { advantage of sunlight. The steel } \\
\text { cables would allow them to hang } \\
\text { their work at exhibition points in } \\
\text { the same way. The triangular } \\
\text { shape of the photovoltaic fabrics } \\
\text { were inspired to fit in with the } \\
\text { marine environment by simulating } \\
\text { the sails of ships. }\end{array}$ & $\begin{array}{l}\text { Socio-emotional learning objective } \\
\text { 1.2.11.3 } \\
\text { The learner is able to reflect on their } \\
\text { region in the development of their } \\
\text { own identity, understanding the } \\
\text { roles that the natural, social, and } \\
\text { technical environments have had in } \\
\text { building their identity and culture. } \\
\text { Cognitive learning objective } \\
\text { 1.2.11.2 } \\
\text { The learner is able to evaluate and } \\
\text { compare the sustainability of } \\
\text { systems in their own and other } \\
\text { settlements in meeting their needs, } \\
\text { particularly in the areas of food, } \\
\text { energy, transport, water, safety, } \\
\text { waste treatment, inclusion and } \\
\text { accessibility, education, integration } \\
\text { of green spaces, and disaster risk } \\
\text { reduction. } \\
\text { Cognitive learning objective } \\
\text { 1.2.11.5 } \\
\text { The learner understands the role of } \\
\text { local decision-makers and } \\
\text { participatory governance and the } \\
\text { importance of representing a } \\
\text { sustainable voice in planning and } \\
\text { policy for their area. }\end{array}$ & $\begin{array}{l}\text { Critical thinking competency: } \\
\text { The ability to question norms, } \\
\text { practices, and opinions; to reflect } \\
\text { on their own values, perceptions, } \\
\text { and actions; and to take a position } \\
\text { in the sustainability discourse. } \\
\text { Self-awareness competency: The } \\
\text { ability to reflect on one's own role } \\
\text { in the local community and } \\
\text { (global) society; to continually } \\
\text { evaluate and further motivate } \\
\text { their actions and to deal with their } \\
\text { own feelings and desires. }\end{array}$ \\
\hline
\end{tabular}


Table 6. Phase 4 of the project: Design of the living space. 3D model.

\begin{tabular}{c} 
Phase of the Project \\
\hline The students, using specific techniques \\
and constructive elements from the \\
Technical Drawing area, design their \\
space of opportunity: A rest and \\
meeting area consisting of an ergonomic \\
tier, trees and flowerbeds of vegetal soil \\
games area, and pergola to offer shade. \\
The tier would allow them to hide, rest, \\
foster social relations, and act as an ideal \\
space for relaxed reading as well as for \\
social gatherings. \\
The green area would offer an ecological \\
and pleasant environment. \\
The design of the games is inspired by \\
nature. They design a board game to be \\
projected on the floor, recreating the \\
shape of an ammonite. \\
Around the recreational area, a drain is \\
projected that will collect runoff water \\
when it rains. The objective is to use the \\
same water to irrigate the trees. \\
All the materials used in the project \\
are ecological. \\
Once the design was finished, using
\end{tabular}
advanced computing tools, our students made a 3D design that allows better visualization of the projected environment.

To finish, they created a model in the classroom workshop that provided a physical view of the project.

The students defended their project in the presence of a special panel of the University of Cartagena and were later awarded first prize in the 1st

Architecture Olympiad of the Region of Murcia.
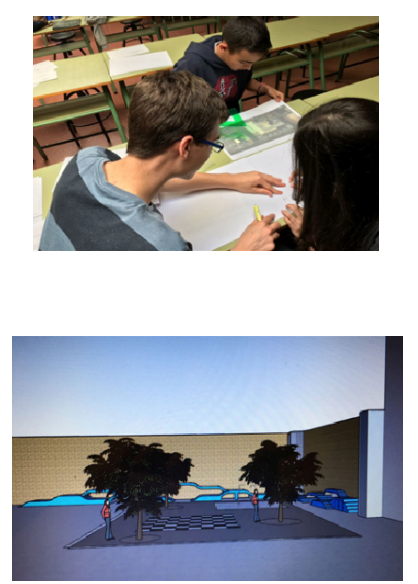

\section{Learning Objective}

Cognitive learning objectives 1.2.11.4

Students know the basic principles of sustainable planning and building, and can identify opportunities for making

their own area more sustainable and inclusive.

Socio-emotional learning objectives 1.2.11.3

The learner is able to reflect on their region in the development of their own identity, understanding the roles that

the natural, social, and technical

environments have had in building their identity and culture.

Behavioral learning objective 1.2.11.1

The learner is able to plan, implement, and evaluate community-based sustainability projects.

Behavioral learning objective 1.2.11.2

The learner is able to participate in and influence decision processes about their community.

Behavioral learning objective 1.2.11.3.

The learner is able to speak and organize their views against/in favor of decisions made for their community.

Behavioral learning objective 1.2.11.4. The learner is able to co-create an inclusive, safe, resilient, and sustainable community

Behavioral learning objective 1.2.11.5

The learner is able to promote low carbon policies at local level.
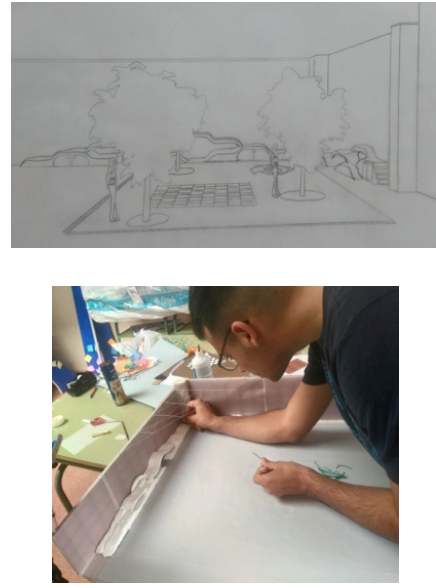

\section{Key Competence}

Strategic competency:

Students develop their abilities to collectively implement innovative actions that further sustainability at local level and further afield.

Collaboration competency:

The students develop the ability to learn from others; to understand and respect the needs,

perspectives, and actions of others (empathy); to understand, relate to, and be sensitive towards others (empathic leadership); to deal with

conflicts in a group; and to facilitate collaborative and participatory problem solving.

Integrated problem-solving competency:

Developing the ability to apply different problem-solving frameworks to complex

sustainability problems and

develop viable, inclusive, and equitable solutions or options that promote sustainable development, integration of the

above-mentioned competencies.
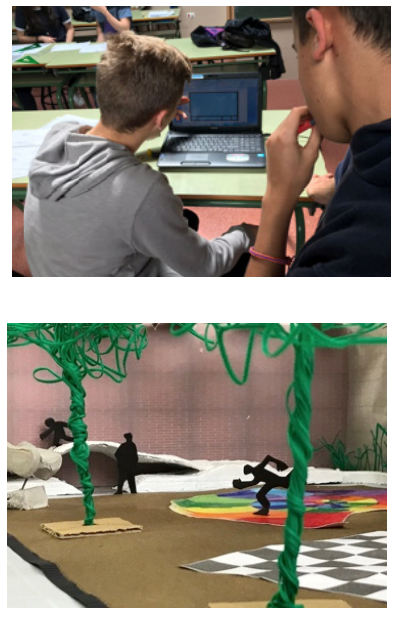

Our students participated in the First Olympiad of Architecture in the Region of Murcia and, with the project detailed above, obtained first prize.

\subsection{Triangulation Instrument (NEP Scale) to Measure the Level of Sustainable Awareness of Participants}

The instrument used to measure sustainable consciousness was the so-called revised NEP Scale. Due to its simplicity of application, this instrument has been widely used by many authors worldwide; the scale is considered appropriate in research into pro-environmental awareness [34]. 
The authors consider that the revised scale better encompasses the various facets of an ecological worldview; balances the number of pro- and anti-NEP items; and updates the terminology of the first version. "This scale assesses attitudes, beliefs, values and worldviews regarding the environment. Previous studies have found different underlying factorial structures, while evidence of internal consistency is acceptable" [35].

This is a 15-item Likert questionnaire that deals with 5 facets of the relationship between humans and the environment [36].

The existence of limits to the growth of human societies -items 1, 6 and 11-; the right of humanity to use nature to its advantage or anti-anthropocentrism-items 2, 7 and 12-; the fragility of the natural balance-items 3, 8, 13-; rejection of human exceptionalism-items 4, 9 and 14-; and the possibility of ecological crises -items 5, 10 and 15-.

The eight odd items are written in such a way that adherence to them indicates a pro-environmental or ecocentric point of view, while the seven items are written so that adherence to them indicates an anthropocentric attitude.

Students fill in the questionnaire, assigning values from 1 to 5 :

$$
1 \text { = Strongly Disagree. } 2 \text { = Disagree. } 3 \text { = Doesn't matter. } 4=\text { OK. } 5=\text { Totally agree }
$$

We therefore have 15 categorical variables whose measurement scale in SPSS will be ordinal. After the students answer the questionnaire, we obtain 15 items, each evaluated from 1 to 5 points each.

As can be observed in Tables 7 and 8, in order to measure the level of sustainable consciousness, two new variables are generated. The first, "ecocentric grouped" variable that makes up the 8 ecocentric items, and a second "anthropocentric grouped" variable formed by the 7 anthropocentric items, thus establishing two new evaluation scales:

Table 7. Clustered Ecocentric Variable.

\begin{tabular}{cc}
\hline \multicolumn{2}{c}{ Clustered Ecocentric Variable } \\
\hline Points & Level of Awareness \\
\hline $0-8$ & Very low \\
$9-16$ & Low \\
$17-24$ & Medium \\
$25-32$ & High \\
$33-40$ & Very High \\
\hline
\end{tabular}

Table 8. Variable: Anthropocentric grouped.

\begin{tabular}{cc}
\hline \multicolumn{2}{c}{ Variable: Anthropocentric Grouped } \\
\hline Points & Level of Awareness \\
\hline $0-7$ & Very low \\
$8-14$ & Low \\
$15-21$ & Medium \\
$22-28$ & High \\
$29-35$ & Very High \\
\hline
\end{tabular}

For the first variable, 8 items and 5 values imply a maximum of 40 points. Table 9 shows the Revised NEP Statements. 
Table 9. Revised NEP (New Environmental Paradigm) Statements.

\section{Revised NEP Statements}

1. We are approaching the limit of the number of people the Earth can support.

2. Humans have the right to modify the natural environment to suit their needs.

3. When humans interfere with nature, it often produces disastrous consequences.

4. Human ingenuity will ensure that we do not make the Earth uninhabitable.

5. Humans are seriously abusing the environment.

6. The Earth has plenty of natural resources if we just learn how to develop them.

7. Plants and animals have as much right as humans to exist.

8. The balance of nature is strong enough to cope with the impacts of modern industrial nations.

9. Despite our special abilities, humans are still subject to the laws of nature.

10. The so-called "ecological crisis" facing humankind has been greatly exaggerated.

11. The Earth is like a spaceship with very limited room and resources.

12. Humans were meant to rule over the rest of nature.

13. The balance of nature is very delicate and easily upset.

14. Humans will eventually learn enough about how nature works to be able to control it.

15. If things continue on their present course, we will soon experience a major ecological catastrophe

For the second variable, 7 items and 5 values imply a maximum of 35 points.

\section{Results}

Table 10 shows the results obtained after applying the methodological approach recommended by UNESCO. Learning objectives and key competencies acquired in each of the four phases of the project.

Table 10. Learning objectives and key competency achieved according to UNESCO (2017).

\begin{tabular}{ccc}
\hline Phase of the Project & Learning Objective & Key Competency \\
\hline $\begin{array}{c}\text { 1-Background and analysis of } \\
\text { current status. }\end{array}$ & Cognitive & $\begin{array}{c}\text { Systems thinking, } \\
\text { Anticipatory competency }\end{array}$ \\
\hline $\begin{array}{c}\text { 2-Social study and feasibility } \\
\text { of the area of action. }\end{array}$ & Socio-emotional & $\begin{array}{c}\text { Anticipatory competency, } \\
\text { Normative competency }\end{array}$ \\
\hline $\begin{array}{c}\text { 3-Approach to the design of } \\
\text { the space of coexistence. }\end{array}$ & Socio-emotional, Cognitive, & Critical thinking, Self-awareness \\
\hline $\begin{array}{c}\text { 4-Design of the living space. } \\
\text { 3D model. }\end{array}$ & $\begin{array}{c}\text { Cognitive, Socio-emotional, } \\
\text { Behavioral }\end{array}$ & $\begin{array}{c}\text { Strategic, Collaboration, Joint } \\
\text { problem-solving }\end{array}$ \\
\hline
\end{tabular}

Tables 11 and 12 show the results of the NEP questionnaire. The environmental awareness levels of the students are high: $77.8 \%$ have a high level of ecocentric awareness, and $22.2 \%$ a very high level. Similarly, $77.8 \%$ of them have an average anthropocentric level, and $22.2 \%$ have a low anthropocentric level.

Table 11. Ecocentrist (grouped).

\begin{tabular}{cccccc}
\hline & Frequency & Percentage & Percentage (Valid) & Percentage (Cumulative) \\
\hline \multirow{3}{*}{ Valid } & High & 7 & 77.8 & 77.8 & 77.8 \\
& Very High & 2 & 22.2 & 22.2 & 100.0 \\
& Total & 9 & 100.0 & 100.0 & \\
\hline
\end{tabular}

Table 12. Anthropocentric (grouped).

\begin{tabular}{cccccc}
\hline & & Frequency & Percentage & Percentage (Valid) & Percentage (Cumulative) \\
\hline \multirow{3}{*}{ Valid } & Low & 2 & 22.2 & 22.2 & 22.2 \\
& Medium & 7 & 77.8 & 77.8 & 100.0 \\
& Total & 9 & 100.0 & 100.0 & \\
\hline
\end{tabular}




\section{Discussion}

Following the announcement in 2015 of the Sustainable Development Goals and 2030 Agenda, national and local governments have begun to follow the guidelines in order to achieve these goals by the 2030 horizon.

Since the start of the journey made in 2016, the Network of Solutions for Sustainable Development, in collaboration with the UN, carried out assessments for different countries, indicating the state of achievement of the SDGs by 2030 horizon. As far as our country is concerned, Spain will not achieve any SDGs by the established date, with several SDGs far from being reached, as is the case of SDG 11 "Sustainable Cities and Communities".

This article proposes a methodological route that, supported by the indications of UNESCO, can serve as a classroom guide to work the SDGs in a transversal way, in the case described SDG 11. The aim is also reinforce Education for Sustainable Development and finally to strengthen the level of sustainable awareness in students. The project presented relate each of its phases to Learning Objectives and Key Competences for SDG 11 "Sustainable Cities and Communities" by means of the methodological approach proposed by UNESCO (2017). The methodology used has focused on students of STEM subjects, in this case technical drawing, is action-oriented and transformative since students, as described in the phases of their eco-urban project, were able to establish sustainable solutions for their environment, in a socio-cultural and historical context, valuing the cognitive, socio-emotional, and behavioral learning objectives for ESD. In the same way, all the objectives are related to the key competencies for sustainability that generally regarded as crucial for attaining sustainable development [25].

We agree with the Action Plan for the implementation of the Spanish Government's 2030 Agenda, as we consider it important that ESD is implemented in educational curricula.

We agree with UNESCO that the type of project presented in this article is a "key learning method for SDGs" [25]. In addition, the project that we present coincides with one of the "Examples of learning approaches and methods for SDG 11 "Sustainable Cities and Communities", Table 1.2.11b" (UNESCO 2017). We agree with Ugarte, A. on the need to communicate SDGs in context, and that they should be adapted socially and culturally [37].

The results obtained are interesting, as they show high levels of sustainable awareness of the importance of the environmental, social, and economic dimensions that underline the principle of sustainability $[38,39]$. The findings have encouraged us to continue working with the NEP in the classroom. Another point worth highlighting is that students have been trained in the environmental competencies and skills reviewed by other authors like Cabero, J.; and Llorente, M. [40]. We agree with Wals (2015) that, by working on these dimensions, we train "sustainable citizens" because this project has allowed us to evaluate Education for Sustainable Development and to work with our students, not only on a given topic, but also on the learning approaches and methods suggested by UNESCO.

Author Contributions: Conceptualization, F.D.C.V. and F.L.R.; methodology, F.D.C.V. and F.L.R.; software, F.L.R.; validation, F.D.C.V.; formal analysis F.D.C.V. and F.L.R.; investigation, F.D.C.V. and F.L.R.; resources, F.D.C.V. and F.L.R.; data curation, F.D.C.V. and F.L.R; writing-original draft preparation F.D.C.V. and F.L.R.; writing-review and editing, F.D.C.V. and F.L.R.; visualization, F.D.C.V. and F.L.R.; supervision, F.D.C.V. and F.L.R.; project administration, F.D.C.V. and F.L.R. All authors have read and agreed to the published version of the manuscript.

Funding: This research received no external funding.

Acknowledgments: Special thanks are due to the group of students who, coordinated by the authors, won first prize in 2018 at the 1st Olympiad of Architecture of the Region of Murcia.

Conflicts of Interest: The authors declare no conflict of interest. 


\section{References}

1. Royal Decree 419/2018, of 18 June, Restructuring the Presidency of the Government. Boletín Oficial Del Estado, 148, 19/06/2018. pp. 61715-61716. Available online: https://www.agenda2030.gob.es/sites/default/ files/recursos/BOE\%20ALTO\%20COMISIONADO\%20.pdf (accessed on 4 May 2019).

2. 2030 Agenda-Government of Spain. Available online: https://www.agenda2030.gob.es/ (accessed on 4 September 2019).

3. Ministry of Foreign Affairs, European Union and Cooperation. Action Plan for the Implementation of Agenda 2030. Towards a Spanish Sustainable Development Strategy. Available online: http://www.exteriores.gob.es/Portal/es/SalaDePrensa/Multimedia/Publicaciones/Documents/PLAN\% 20DE\%20ACCION\%20PARA\%20LA\%20IMPLEMENTACION\%20DE\%20LA\%20AGENDA\%202030.pdf (accessed on 11 September 2019).

4. Development Policy Coherence Index. Report 2016. Available online: https://www.icpd.info/wp-content/ uploads/2016/03/ICPD2016-INFORME-COMPLETO.pdf (accessed on 24 July 2019).

5. Spanish Network for Sustainable Development. (October 2018). Looking to the Future: Sustainable Cities. Available online: https://proyectos.irispressmz.com/thinkeurope/wp-content/uploads/2018/12/ Informe-urbano-REDS-ODS-2018-parte-I.pdf (accessed on 25 July 2019).

6. Spanish Network for Sustainable Development. Launch of the Sustainable Development Report 2019 (Formerly SDG Index). 2019. Available online: http://reds-sdsn.es/sdg-index-2019 (accessed on 20 September 2019).

7. Ministry of Education and Vocational Training. Available online: http://www.educacionyfp.gob.es/alemania/ dam/jcr:95dcf9d7-d830-4022-9df7-04c537268f80/dinamarca2014.pdf (accessed on 26 July 2019).

8. Ministry of Education and Vocational Training. Available online: https:/www.educacionyfp.gob.es/alemania/ dam/jcr:c5b26728-e2bc-4e41-80db-1d48c003f75e/finlandia2014.pdf (accessed on 28 July 2019).

9. UNESCO. The Main Lines of Emphasis of the Tbilisi Conference. 1980. Available online: https://unesdoc. unesco.org/ark:/48223/pf0000038550_spa (accessed on 2 September 2019).

10. United Nations. Brundtland Report of the World Commission on Environment and Development. 1987. Available online: http://www.exteriores.gob.es/Portal/es/PoliticaExteriorCooperacion/Desarrollosostenible/ Documents/Informe\%20Brundtland\%20(En\%20ingl\%C3\%A9s).pdf (accessed on 22 February 2020).

11. Benayas, J.; Gutierrez, J.; Hernández, N. Research in Environmental Education in Spain. Available online: https://www.miteco.gob.es/en/ceneam/grupos-de-trabajo-y-seminarios/investigacion/investigacioneducacion-ambiental-espana_tcm38-167492.pdf (accessed on 22 February 2020).

12. Bauer, D.; Arnold, J.; Kremer, K. Consumption-Intention Formation in Education for Sustainable Development: An Adapted Model Based on the Theory of Planned Behavior. Sustainability 2018, 10, 3455. [CrossRef]

13. Rodrigo-Cano, D.; Gutierrez, J.M.; Ferreras, J. 35 Years of Success in Environmental Education in Spain. Available online: http://www.eduso.net/res/winarcdoc.php?id=1191 (accessed on 22 February 2020).

14. Sauvé, L. Environmental Education and Eco-Citizenship. Key Dimensions of a Pedagogical-Political Project. 2014. Available online: https://revistas.udistrital.edu.co/index.php/revcie/article/view/5558/7072 (accessed on 23 February 2020).

15. Del Cerro, F.; Lozano, F. Study of a case of teaching STEM subjects through ecourbanism supported by advanced design tools, in the 2030 horizon of sustainable development objectives (SDGs). RED 2018, 58, 13.

16. Ferrer, E.A.; Lazo, J.; Pierra, A. University and Sustainable Development. Available online: http://cvi.mes. edu.cu/peduniv/index.php/peduniv/article/view/292/283 (accessed on 21 February 2020).

17. SDG Index and Dashboards Report for European Cities (Prototype Version). 2019. Available online: https://s3.amazonaws.com/sustainabledevelopment.report/2019/2019_sdg_index_euro_cities.pdf (accessed on 28 August 2019).

18. UNESCO. Global Programme of Action for Education for Sustainable Development. Available online: https://es.unesco.org/gap (accessed on 30 August 2019).

19. Querol, X. Urban Air Quality in Europe: Scientific and Environmental Policy Challenges; Paper at the XV Spanish Congress on Environmental Health; Spanish Society for Environmental Health: Valencia, Spain, 2019.

20. El Diario. In Europe There Are 280 Cities with Traffic Restriction Zones; in Spain, One. Available online: https://www.eldiario.es/ballenablanca/transicion_energetica/ciudades-Europa-restriccion-traficoEspana_0_870713415.html (accessed on 13 September 2019). 
21. World Health Organization. Air Pollution. Available online: https://www.who.int/health-topics/airpollution\#tab=tab_1 (accessed on 18 September 2019).

22. Ministry of Ecological Transition. National Energy Poverty Strategy 2019-2024. Available online: https://www. miteco.gob.es/es/prensa/estrategianacionalcontralapobrezaenergetica2019-2024_tcm30-496282.pdf (accessed on 10 October 2019).

23. UNESCO. Education Needs to Change Fundamentally to Meet Global Development Goals. 2016. Available online: http://www.unesco.org/new/en/media-services/single-view/news/education_needs_to_ change_fundamentally_to_meet_global_devel/ (accessed on 13 October 2019).

24. Machín, F.; Céspedes, S.; Riverón, A.; Fernández, E. Sustainability, engineering and teaching of basic sciences. Conceptual Theoretical Framework. RIE 2017, 73, 179-202.

25. UNESCO. Education for Sustainable Development Goals: Learning Objectives. 2017. Available online: https://www.iau-hesd.net/sites/default/files/documents/247444e.pdf (accessed on 27 June 2019).

26. Kioupi, V.; Voulvoulis, N. Education for Sustainable Development: A Systemic Framework for Connecting the SDGs to Educational Outcomes. Sustainability 2019, 11, 6104. [CrossRef]

27. Wals, A.E.J. Beyond Unreasonable Doubt; Education and Learning for Socio-Ecological Sustainability in the Anthropocene; Wageningen University: Wageningen, The Netherlands, 2015.

28. Gomera, A.; Villamandos, F.; Vaquero, M. Construction of Indicators of Environmental Beliefs from the NEP Scale. 2013. Available online: http://revistas.uned.es/index.php/accionpsicologica/article/view/7041/10261 (accessed on 23 July 2019).

29. Gomera, A. Environmental Awareness as a Tool for Environmental Education: Conclusions and Reflections from a University Study. 2008. Available online: https://www.miteco.gob.es/ca/ceneam/articulos-de-opinion/ 2008_11gomera1_tcm34-163624.pdf (accessed on 24 July 2019).

30. Holden, E.; Linnerud, K.; Banister, D. Sustainable Development: Our Common Future Revisited. 2014. Available online: https://reader.elsevier.com/reader/sd/pii/S0959378014000727?token= 10150C7D4EA256ED768999BCCE991D09B279578B3B0F95382F1BE45E3041418F838AD119B24BA9D510D76741066044DD (accessed on 17 March 2020).

31. Aragonés, J.I.; Amérigo, M. Environmental Psychology; Piramide: Salamanca, Spain, 1998; pp. 325-329.

32. Moyano, E.; Palomo, G. Psychometric Properties of the New Ecological Paradigm Scale (NEP-R) in the Chilean Population. Psico 2014, 45, 415-423. [CrossRef]

33. Dunlap, R.; Van Liere, K.; Mertig, A.; Jones, R. New trends in measuring environmental attitudes: Measuring endorsement of the new ecological paradigm: A revised NEP scale. J. Soc. Issues 2000, 56, 425-442. [CrossRef]

34. Vozmediano, L.; San Juan, C. New Ecological Paradigm Scale: Psychometric Properties with a Spanish Sample Obtained through the Internet. 2005. Available online: https://mach.webs.ull.es/PDFS/Vol6_1/VOL_6_1_d.pdf (accessed on 22 September 2019).

35. Reyna, C.; Bressan, E.; Mola, D.; Belaus, A.; Ortiz, M. Structural Validity of the New Ecological Paradigm Scale in Argentine Citizens Using Different Approaches. 2017. Available online: https://revistas.javerianacali. edu.co/index.php/pensamientopsicologico/article/view/1588/2303 (accessed on 29 September 2019).

36. Cerrillo, J. Measuring Environmental Awareness: A Critical Review of Riley E.'s Work. Dunlap. 2010. Available online: https:/ddd.uab.cat/pub/athdig/15788946n17/15788946n17p33.pdf (accessed on 6 October 2019).

37. Ugarte, A. Communicating Sustainable Development Objectives in the Post-Truth Era. 2017. Available online: https://comunideas.com/comunicar-los-ods-en-la-era-de-la-posverdad/ (accessed on 6 November 2019).

38. Melek, Y.; Sprenger, S.; Kremer, K. High-School Students' Conceptions of Sustainability and Sustainable Water Consumption-A Collaborative Study between Germany and Turkey. 2019. Available online: https://eera-ecer.de/ecer-programmes/conference/24/contribution/47442/ (accessed on 4 March 2020).

39. Del Cerro, F.; Lozano, F. Ecourban Technical Project supported by ICT for STEM learning (Technical Drawing) and the consolidation of SDG in the classroom. RED 2019, 60, 15.

40. Cabero, J.; Llorente, M. ICTs and Environmental Education. RLTE 2005, 4, 9-26.

(C) 2020 by the authors. Licensee MDPI, Basel, Switzerland. This article is an open access article distributed under the terms and conditions of the Creative Commons Attribution (CC BY) license (http://creativecommons.org/licenses/by/4.0/). 